\title{
Modeling the Impacts of Land Cover Changes on Stream Flow Response in Thiba River Basin in Kenya
}

\author{
Samuel M. Kasuni ${ }^{1,}$, , Johnson U. Kitheka ${ }^{2}$ \\ ${ }^{1}$ Department of Water and Waste Water Engineering, Kenya Water Institute, Nairobi, Kenya \\ ${ }^{2}$ Department of Hydrology and Water Resources Management, South Eastern Kenya University, Kitui, Kenya
}

\section{Email address:}

skasuni@yahoo.com (S. M. Kasuni),kolbio_Kolbio@yahoo.com (J. U. Kitheka)

${ }^{*}$ Corresponding author

\section{To cite this article:}

Samuel M. Kasuni, Johnson U. Kitheka. Modeling the Impacts of Land Cover Changes on Stream Flow Response in Thiba River Basin in Kenya. Journal of Water Resources and Ocean Science. Vol. 6, No. 1, 2017, pp. 1-13. doi: 10.11648/j.wros.20170601.11

Received: January 10, 2017; Accepted: January 21, 2017; Published: February 10, 2017

\begin{abstract}
Soil and Water Assessment Tool (SWAT) was used to model the impacts of land cover changes on stream flow regime in the Thiba River basin covering a surface area of $1648 \mathrm{~km}^{2}$ in central region of Kenya. The basin is characterized by intensive agricultural activities including the largest rice irrigation scheme in Kenya. A study was undertaken to test the capability of the model in predicting stream flow response under changing land use conditions in a typical tropical river basin. Classified land use maps of 1984, 2004 and 2014 were analyzed to investigate land use changes in the basin. Field based survey, National Irrigation Board (NIB), Kenya Meteorological Department and Water Resources Management Authority (WRMA) provided hydro-meteorological data for the study. The results of the study shows that forest cover in the Thiba River basin has decreased by $18.39 \%$ between 1984 and 2014 while area under rice cultivation increased by $9.38 \%$ in the same period. The SWAT Model results showed that there is a significant relationship between the observed and simulated average monthly stream flows in the Thiba River Basin. The Nash-Sutcliffe Efficiency (NSE) and coefficient of determination ( ${ }^{2}$ ) during calibration period (1983-1988) were 0.82 and 0.9, respectively, while for the validation period (1989-1993) they were 0.79 and 0.87 , respectively. The average monthly stream flows increased by $6.01 \mathrm{~m}^{3} / \mathrm{s}$ during the wet season and decreased by $1.92 \mathrm{~m}^{3} / \mathrm{s}$ during the dry season. The changes in stream flow were attributed to the land cover change and rainfall variability. About $35 \%$ of dry season flow and 3\% of wet season flow was found to have been directly abstracted from the Thiba River. The study recommends that the basin stakeholders should optimize utilization of abstracted water to avert future catastrophic stream flow fluctuations, possibly flooding during the wet season and low or dry riverbeds during the dry months. The high water demand in the dry months can be met by constructing water storage reservoirs to harvest the high runoff during the wet months. Also, it's important that further research on impact of climate change be conducted to better understand the relationship between catchment hydrology and climate change.
\end{abstract}

Keywords: Arc-SWAT Model, Hydrological Modeling, Land Use and Land Cover Change, Thiba River Basin, Kenya

\section{Introduction}

This study focused on establishing the impacts of agriculture and land use change on the flow of tropical river systems focusing on the Thiba river in Eastern Kenya. The relationship between land use and hydrology was of interest to hydrologists as it can provide crucial information for water resources management actions. This was important for avoiding or minimizing the negative effects of land use activities on the hydrology of tropical river systems. In general, a change in land use from natural vegetation to agricultural crops often results in a drop in rainfall interception rates, a rapid delivery of storm flow to streams, and a reduction in infiltration capacity of the soils due to compaction [1]. The largest changes in terms of land area, and arguably also in terms of hydrological impacts, often arise from a forestation and deforestation activities. One of the direct effects of land use changes on hydrology and hence 
on water resources is through its link with the evapotranspiration regime. Any change in land use and vegetation cover can have impacts on potential and actual evapotranspiration as well as the discharge regime, which reflects the integrated behavior of all the hydrological processes acting in the catchment [2]. Many studies associate higher catchment forest cover with lower base flows, attributed to high evapo-transpiration rates of forests, while other studies indicate increased base flow with higher watershed forest cover due to higher infiltration and recharge of subsurface storage. The demonstrated effects of agriculture and urbanization are also inconsistent, due to varied additions of imported water and extremely variable background conditions [3].

In Kenya, quantity and flow patterns of surface water resources particularly rivers depend on: basin shape, vegetation cover in the basin, rainfall intensity, seasonality plus human settlement and land use patterns [4]. Upstream rainfall variability and flow abstraction for irrigation are key parameters in understanding low flows in river [5]. Decrease in rainfall reduces inflow into surface water bodies, while at the same time they increase the irrigation water requirements. A number of studies have been undertaken on the impact of irrigation water abstraction on stream flow. A study in upper Ewaso Ngiro basin in North Eastern Kenya found that 60-80 percent of available water in upper reaches was abstracted for irrigation [6]. The overabstraction of water from the river has been taking place since the introduction of horticulture crops for export market in 1984. The high level of irrigation water abstraction in the upper reaches of the river was mainly due to the hydraulic and hydrologic advantage, suitability for irrigation development and access to market. This overabstraction has been blamed for decreasing water availability in lower reaches resulting to water conflicts [6]. A study by [4] on the effect of water abstraction for irrigation use in semi-arid Baringo District established that irrigation projects in the semi-arid lands of Kenya have had negative impacts on the surface water resources and the aquatic life. Abstraction of water from rivers flowing into Lake Baringo caused a reduction in the lakes surface area from $144 \mathrm{~km}^{2}$ in 1980 to $112 \mathrm{~km}^{2}$ in 1995 while the depth reduced from $2.2 \mathrm{~m}$ in 1985 to $1.7 \mathrm{~m}$ in 1995 [4]. Thiba river basin past studies have focused on irrigation water efficiency use on the Mwea Irrigation Scheme (MIS) which has existed since 1956. Since 1998 to date, about 4000 acres of land has been developed by farmers on their own for paddy cultivation [7]. This new area was not planned for and has worsened the situation in terms of water availability for the scheme. However there is a paucity of knowledge on actual water abstracted from the basin and land use change associated with increased commercial agricultural activities in the basin. More land is being created from existing forested and other natural vegetation for both irrigated and rain fed high value crops. The Basin has experienced dynamic flow regimes due to changes in land use/cover, deforestation, and increased agricultural activities leading to over-abstraction. This has resulted in reduced water availability during the dry season in different reaches of the basin thus catalyzing conflicts over the finite water resource between different stakeholders, environmental degradation, and reduced hydropower production at Kaburu dam [8]. The main goal of this study was to assess the effect of land use change and increased agricultural water demand on the flow regime of Thiba river so as to generate knowledge and information that could be useful in the allocation of river water among different water uses in the basin. The study also aimed at generating recommendations on the best practices in line with Integrated Water Resources Management (IWRM) to minimize the negative impact of land use change and increased agricultural water abstractions in the Thiba river flow regime in Kenya.

\section{Materials and Methods}

\subsection{The Study Area}

The Thiba basin is located in Kirinyanga and Embu Counties in central region of Kenya (Fig. 1). It is located within longitude $37^{\circ} 40^{\prime}$ and $37^{\circ} 20^{\prime} \mathrm{E}$ and Latitude $0^{\circ} 5^{\prime}$ and $0^{\circ} 10^{\prime} \mathrm{S}$ covering a land area of about $1648 \mathrm{~km}^{2}$. The basin is situated in the upper region of the Tana River Catchment that is drained by the Thiba, Nyamidi, and Rupigazi Rivers and other several streams draining into the Tana river, the largest river system in Kenya. The basin lies at an elevation of between $1,158 \mathrm{~m}$ and 5,380 $\mathrm{m}$ above sea level in the South and at the Peak of Mt. Kenya, respectively. The basin is characterized by high irrigation water abstraction and intensive agricultural activities. The Long Rain season lasts from around March to May with peaks in the month of April when the mean monthly rainfall reaches $2146 \mathrm{~mm}$. The short rain season occurs from September to November with peaks in November with a mean monthly rainfall of $1212 \mathrm{~mm}$ [9]. The temperature in the Thiba River Basin ranges from a mean of $8.10^{\circ} \mathrm{C}$ in the upper zones to $30.3^{\circ} \mathrm{C}$ in the lower zones during the hot season. Potential evapotranspiration in the basin ranges from $1700 \mathrm{~mm}$ in the low elevation savannah zone to less than $500 \mathrm{~mm}$ in the upper region of the basin. All areas below the forest zone have a rainfall-evapotranspiration deficit. As a consequence, the high elevation forest and moorland zones provide most of the discharge of the rivers during the dry periods [10]. The dominant soil types of the Thiba catchment areas presented in Fig. 2 show a clear relationship with elevation of plain land adjacent to volcanic mountain. 


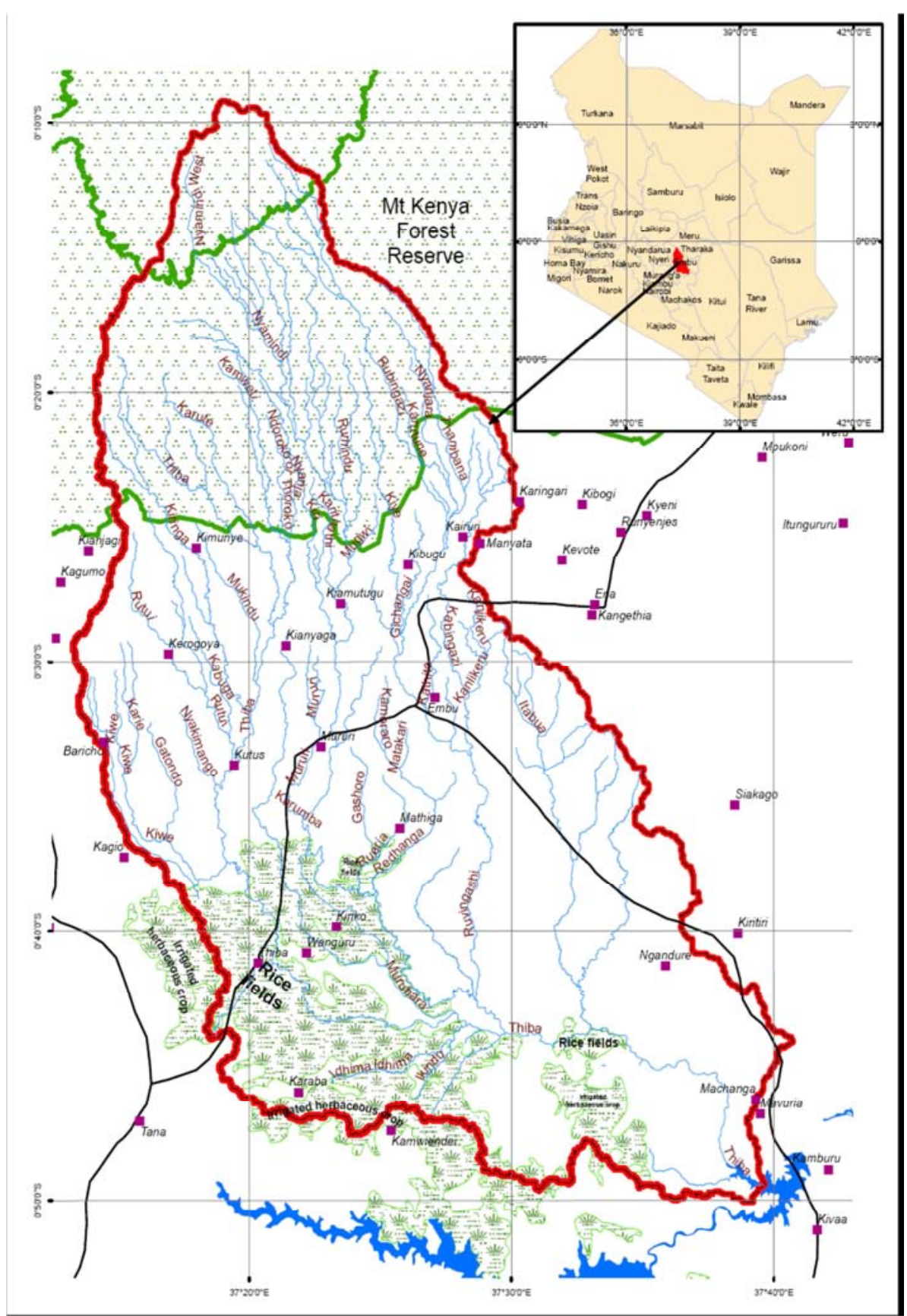

Figure 1. The extent of Thiba Catchment Basin including the main roads and urban centers in the basin.

The higher slopes of Mt. Kenya are dominated by Nitisols. These soils have been formed from volcanic ash deposits. Though they have undergone series of weathering, they are far more productive than most other red tropical soils [11]. Humic Nitisols are well drained, deep, dark friable red soils thus suitable for agricultural activities. The soils have mainly been cultivated with tea, coffee and food crops such as maize. Hitisols are highly resistant to soil erosion but if exposed to poor land management practices, high precipitation received in those high altitude areas can result to excessive soil loss resulting to soil degradation [12]. At lower elevations especially $1000 \mathrm{~m}$ above the sea level, ferrasols and vertisols are the dominant soil types [11]. The soils have been modified from original parent material due to weathering. Vertisols are imperfectly drained to poorly drained, very deep, dark reddish brown to very dark grey, mottled, friable to firm, silty clay to clay; in places stratified and cracking. This makes them suitable for paddy rice farming. On the other hand ferrasols found in the southeastern part of the basin are excessively drained to moderately well drained, moderately deep to deep, dark red to dark grey, loose to friable, sandy loam to clay; in places stony, rocky and bouldery. Land use in Thiba basin can be divided into three classes: natural vegetation (forest, grassland and wetlands), rain-fed and irrigated agriculture (maize, horticulture and rice) and rangeland. The predominant land-use activity in the area is commercial floodirrigation of rice in a scheme (MIS). The scheme started back 
in 1956 with irrigated area of 5,890 acres. Currently it has a gazette area of 30,350 acres of which 16,000 acres for rice production while the rest is used for settlement, public utilities, subsistence and horticultural crop farming [13]. The scheme is served by two main rivers namely Nyamidi and Thiba rivers.

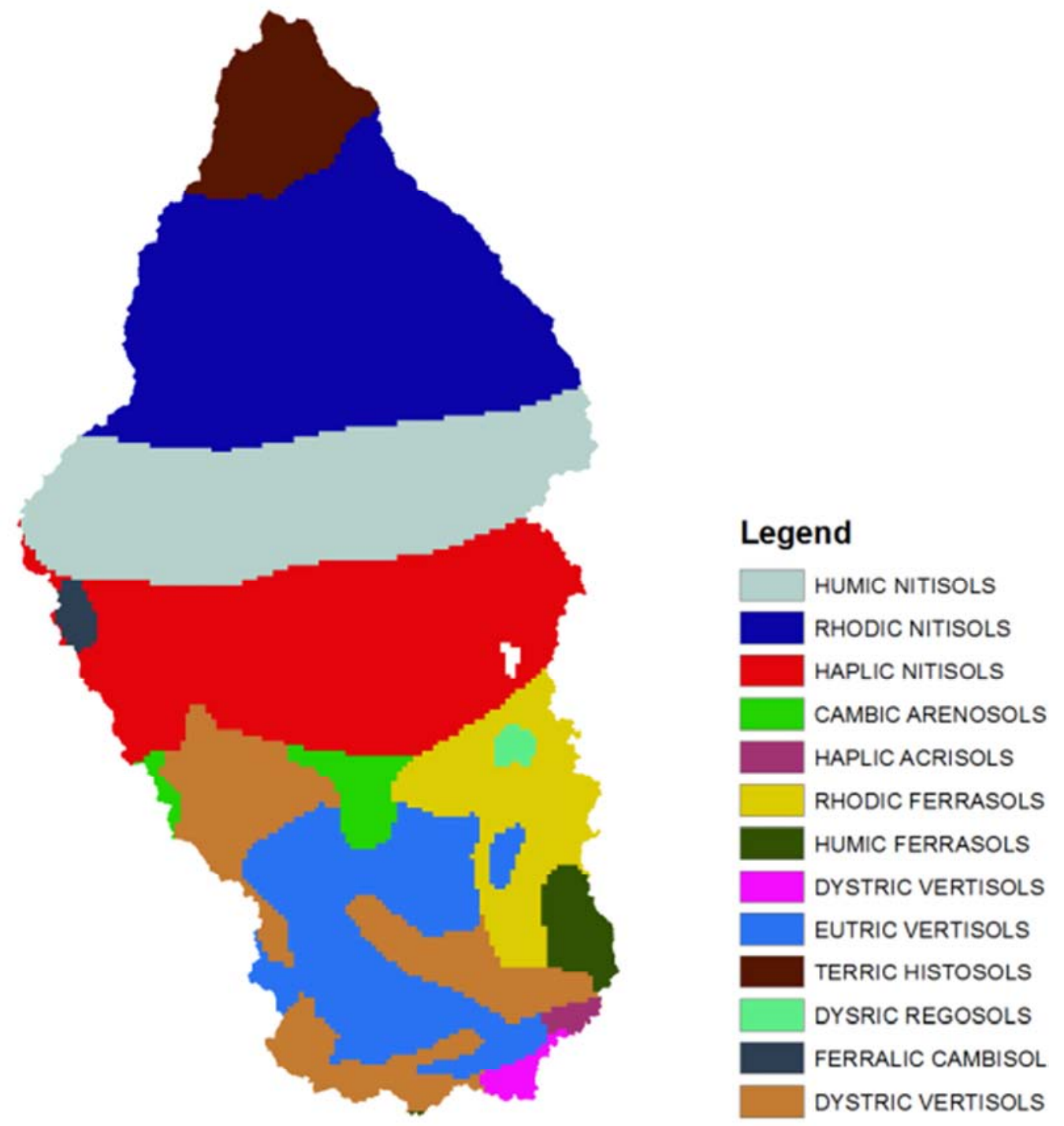

Figure 2. Spatial distribution of soils in Thiba river basin.

\subsection{Data Acquisition}

\subsubsection{Hydro-Meteorological Data}

Stream flow data for Thiba River for the period between 1980 to 1993 was obtained from Water Resources Management Authority (WRMA) in Embu for river gauging station (RGS) 4DD02 located at $0.43^{\circ} \mathrm{S} 37.506^{\circ} \mathrm{E}$ (Fig. 3). Daily observed rainfall data for 20 years (1990-2010) was obtained from Kenya Meteorological Department (KMD) in Nairobi, Kenya.

\subsubsection{Topographic, Soil and Land Use/Cover Data}

A 30 m resolution Digital Elevation Model (DEM) derived from elevation data of the Shuttle Radar Topography Mission (SRTM) was obtained from United States Geological Survey (USGS) website (https://lta.cr.usgs.gov). Soil map was downloaded from Soil and Terrain (SOTER) database for upper Tana River catchment at the scale of 1:250,000 [14]. Land sat image covering Thiba basin for the year 1984 was downloaded from www.http://earth.explorer.usgs.gov obtained by 4-5 TM MSS series. Classified land use polygon maps at scale of 1:250 000 for the years 2004 and 2014 was downloaded from AFRICOVER project database [15]. The land cover was produced from visual interpretation of digitally enhanced LANDSAT TM images (Bands 4, 3, 2).

\subsubsection{Satellite Based Weather Data}

The satellite based daily weather data (rainfall, maximum and minimum air temperature, solar radiation, relative humidity and wind speed) for 13 years (1980-1993) was downloaded from the weather database of Soil and Water Assessment Tool (SWAT) globalweather.tamu.edu website. 


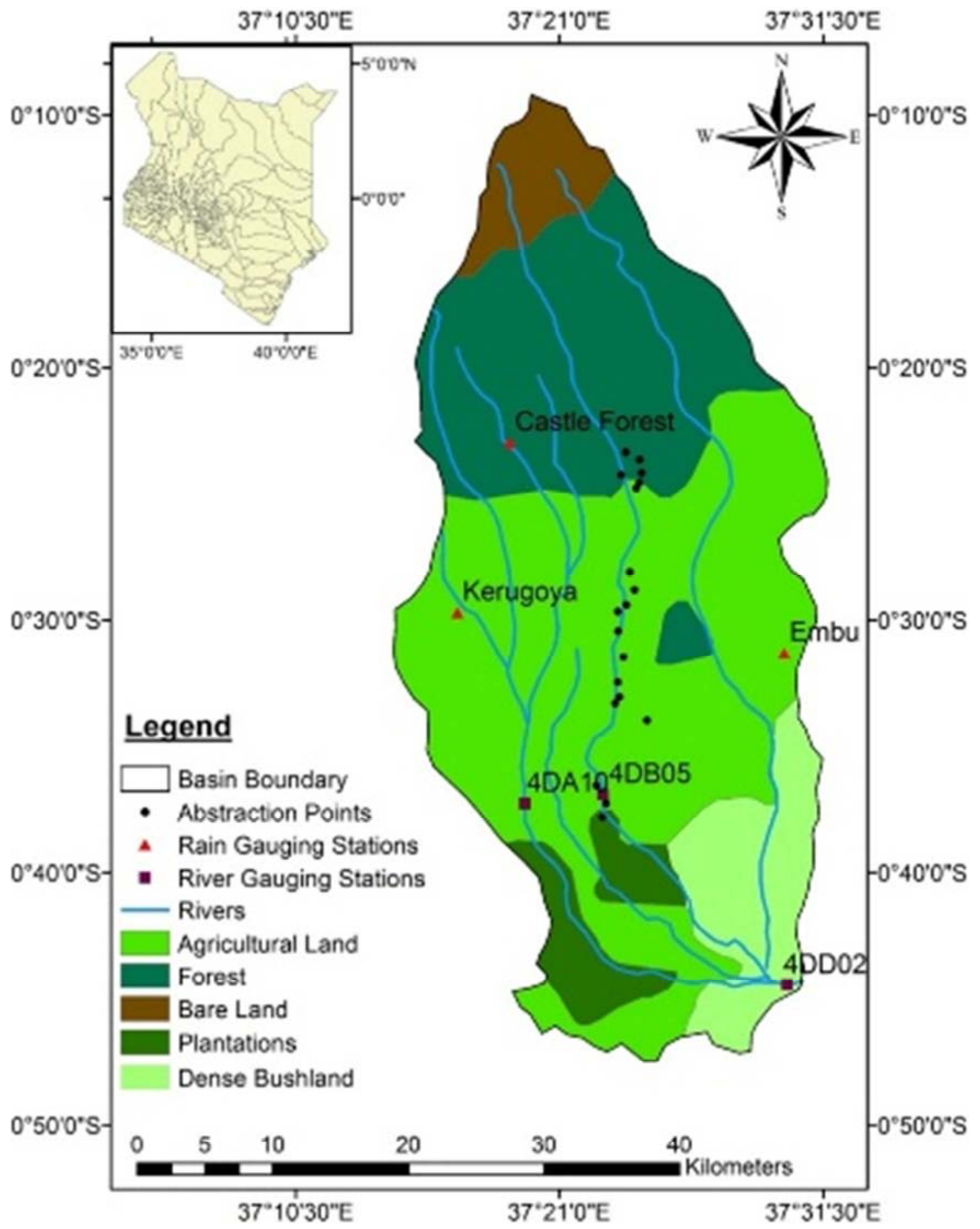

Figure 3. Spatial distribution of rainfall and river gauging stations contributing to data used in this study.

\subsection{Data Processing}

\subsubsection{Land Use and Land Cover Classification}

Supervised image classification process for producing land cover map for the year 1984 as shown in Fig. 4 was followed using Environment for Visualizing Images (ENVI 5.1) remote sensing software. With guidance from historical information gathered during field survey and classified images for land use for 2004 obtained from Africover database, the image was classified to nine classes namely:
Forest, rain fed agriculture, irrigated agriculture, bare land, shrubs, herbaceous plants, rice, urban area and water. Image accuracy was assessed through applying the end members of classified images of 2004. In order to justify the accuracy of temporal image classification, rule-based rationality change detection evaluation according [16] was applied. For this method, 300 random points were taken from the classified 2004 image. The overall accuracy was calculated based on total number of true (correctly classified) pixels based on the rules defined by [16]. 


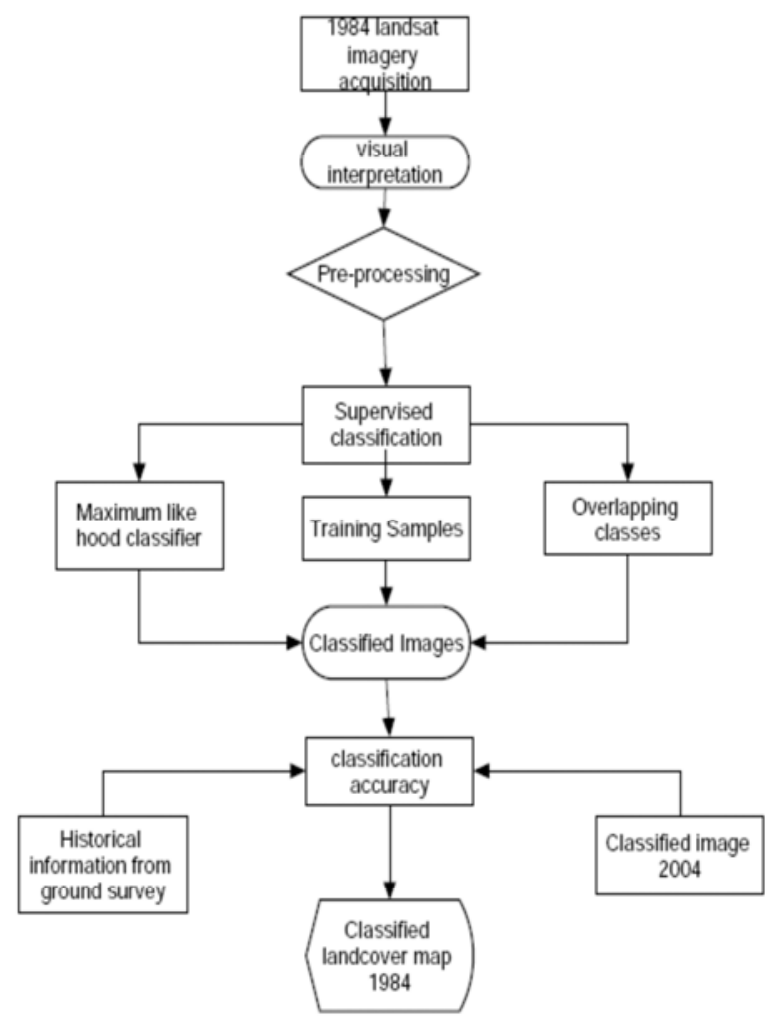

Figure 4. Process of producing land use map for the year 1984.

The classified land use maps were reclassified to into SWAT land uses and land use codes as required by the SWAT model as shown in the Table 1.

Table 1. Reclassification of land use types to SWAT land use classes.

\begin{tabular}{lll}
\hline User Land use & SWAT Land use & $\begin{array}{l}\text { SWAT Land use } \\
\text { code }\end{array}$ \\
\hline Irrigated Agriculture & Generic & AGRL \\
Rain fed Agriculture & Row Crops & AGRR \\
Forest & Mixed Forest & FRST \\
Rice & Rice & RICE \\
Shrubs & Range Shrub Land & RNGB \\
Herbaceous plants & Grass land & RNGE \\
Bare land & Quarries/Mines & SWRN \\
Urban and Buildup area & Urban medium Density & URML \\
Water & Water & WATR \\
\hline
\end{tabular}

$$
\mathrm{SWt}=S W o+\sum_{i=1}^{t}(R d a y+Q \operatorname{surf}-E a-W \text { seep }-Q g w)
$$

in which $S W_{t}$ is the final soil water content (mm), $S W_{0}$ is initial soil water content on day $i(\mathrm{~mm}), t$ is the time (days), Rday is the amount of precipitation on day $i(\mathrm{~mm})$, Qsurf is the amount of surface runoff on day $i(\mathrm{~mm}), E a$ is the amount of evapotranspiration on day $i(\mathrm{~mm})$, Wseep is the amount of water entering the vadose zone from the soil profile on day $i$ (mm), and $Q g w$ is the amount of return flow on day $i(\mathrm{~mm})$. SWAT model requires basic data input before simulation can be performed: DEM, soil layers, land use and climatic data [17]. In this study a 30 DEM and smaller area (4998 ha) was input to get all sub-basin of the Thiba river basin and the outlet

\subsubsection{SWAT Model Set-Up}

The SWAT model is a physically-based continuous time, spatially distributed model designed to simulate water, sediment, nutrient and pesticide transport at a catchment scale on a daily time step. The model was developed by the U.S. Department of Agricultural Research Service (ARS) and scientists at Universities and research agencies around the world [17]. Arc SWAT extension of Arc GIS is a graphical user interface for the SWAT model. The SWAT model is developed and refined by the water balance equation (1) is the base of the hydrologic cycle simulation in SWAT:

was defined, in which it is later taken as a point of calibration of the simulated flows. As a result, there were 17 sub-basins of the Thiba catchment. The watershed was divided into subbasins by overlaying reclassified land use, soil map and slope classes, then further sub-divided into lumped units called Hydrologic Response Units (HRUs), having unique land use and soil combinations. Validated weather data: included daily rainfall, maximum and minimum temperatures, relative humidity and wind speed for the period between 1980 and 1993 corresponding to observed stream flow data was input into the model for stream flow simulation. 


\subsubsection{Model Performance Evaluation}

SWAT is a comprehensive, semi-distributed river basin model that requires a large number of input parameters making model complicated. The input parameters are process based and must be held within a realistic uncertainty range [18]. Model evaluation in this study was conducted through three steps namely: sensitivity analysis, calibration and validation processes.

Sensitivity analysis is the process of determining the rate of change in model output with respect to changes in model inputs (parameters). It is necessary to identify key parameters and the parameter precision required for calibration [19]. In this study, global sensitivity analysis was conducted with 800 simulations giving insight to the most sensitive parameters.

Calibration is the process of estimating the values of model parameters which cannot be accessed directly from the field data. Hydrological models like SWAT contain many parameters which can be classified into two groups: physical and process parameters. A physical parameter represents physically measurable properties of the watershed and whereas process parameters represent properties of the watershed which are not directly measurable [20]. Calibration can be accomplished manually or using auto calibration tools in SWAT [21] or Soil Water Assessment Tool-Calibration and Uncertainty Programme (SWATCUP)[22]. This study adopted auto calibration tool SWATCUP as opposed to manual calibration which is considered outdated and unacceptable according to [23]. The sensitivity of 22 parameters which affects hydrology were tested with SUFI 2 algorithm being used for optimization of the parameters Model validation is the process of demonstrating that a given site-specific model is capable of making sufficiently accurate simulations, although "sufficiently accurate" can vary based on project goals [24]. The model was calibrated with observed monthly stream flow data for the year 1983 to 1988 and validation 1989 to 1993 following an advice by WRMA that data from the year 1993 onwards was deteriorated. However, the flow had been simulated for fourteen years (1980-1993) including three year of the warmup period to allow hydrologic processes to achieve initial equilibrium. Data limitation for calibration and validation has also in the past been experienced in a similar study assessing the impact of climate change on stream flow within lake Victoria basin in Kenya by [25]. They used aggregated monthly data rather than daily data since only 5 year stream flow data was available for model evaluation.

An extensive array of statistical techniques can be used to evaluate SWAT hydrologic and pollutant predictions. In this study the model was evaluated using coefficient of determination $\left(\mathrm{r}^{2}\right)$ and NSE which according to [26] are the most recommended methods for comparing monthly simulated against measured flows as described by equation 2 and equation 3 .

$$
R^{2}=\left\{\frac{\sum_{i=1}^{n}\left(q_{o b s}-\overline{q_{o b s}}\right)\left(q_{s i m}-\overline{q_{s l m}}\right)}{\left[\sum_{i=1}^{n}\left(q_{o b s}-\overline{q_{o b s}}\right)^{2}\right]^{0.5}\left[\sum_{i=1}^{n}\left(q_{s i m}-\overline{q_{s l m}}\right)^{2}\right]^{0.5}}\right\}
$$

Where $\mathrm{R}^{2}$ is coefficient of determination, $\mathrm{q}_{\mathrm{obs}}$ is observed discharge and $\mathrm{q}_{\text {sim }}$ is simulated discharge. The $\mathrm{r}^{2}$ statistic can range from 0 to 1 , where 0 indicates no correlation and 1 represents perfect correlation, and it provides an estimate of how well the variance of observed values are replicated by the model predictions [27].

$$
E=\frac{\sum_{i=1}^{n}\left(Q_{O}-Q_{a v}\right)^{2}-\sum_{i=1}^{n}\left(Q_{O}-Q_{S}\right)^{2}}{\sum_{i=1}^{n}\left(Q_{O}-Q_{a v}\right)^{2}}
$$

Where $\mathrm{E}$ is the Nash-Sutcliffe Efficiency (NSE), $\mathrm{Q}_{0}$ is the observed discharge, Qav is the average observed discharge, and Qs is the simulated discharge. NSE values can range between $-\infty$ to 1 and provide a measure how well the simulated output matches the observed data along a 1:1 line (regression line with slope equal to 1). A perfect fit between the simulated and observed data is indicated by an NSE value of 1 . NSE values $\leq 0$ indicate that the observed data mean is a more accurate predictor than the simulated output.

\subsubsection{Impacts of Land Use Change on Stream Flow}

SWAT is a deterministic model thus each successive model run that uses the same inputs will produce the same outputs. This type of model is preferred for isolating hydrologic response to a single variable, such as land cover and land use change (e.g., management decisions), allowing the impact of any change to be isolated and analyzed for its effect on hydrologic response [28]. Ideally, a model should be nonstationary (such as SWAT) or be able to account for parameter variation through time.

Hydrological monthly stream flow simulations as result of two land use maps generated i.e.1984 and 2014 were independently conducted while keeping all other data inputs constant to understand the impact of land use change on stream flow. Of particular interest were the peak flows and low flows since land use has great impact on proportion of rainfall that converts to stream flow. Seasonal stream flow variability of 1984 and 2014 due to the land use and land cover change was assessed and comparison were made on surface runoff contributions to stream flow based on the two simulation outputs.

\section{Results and Discussion}

\subsection{Land Use and Land Cover Changes}

The results of the analysis of land use and land cover changes in the Thiba river basin (Fig.4) and (table 2) showed that between 1984 and 2004, there has been $12.19 \%$ decrease in forest cover while in the period between 2004 and 2014, there has been a $6.2 \%$ decrease in forest cover. This reduction can be attributed to clearing of forests for agriculture, and increased demand of timber and fuel due to increase in population. The forest land has mainly been cleared to create room for rain fed agriculture as it can be observed from the land use maps for 1984, 2004 and 2014. Rain fed agriculture increased by $8.5 \%$ between 1984 and 2004 while between 2004 and 2014, there was $4.99 \%$ increase. The analysis also 
showed that the area under rice production has increased by $7.79 \%$ between 1984 and 2004 and $1.59 \%$ between 2004 and 2014. The decrease in irrigated agriculture mainly maize at the lower elevations of study area can be attributed to people turning to rice production due to high profitability.
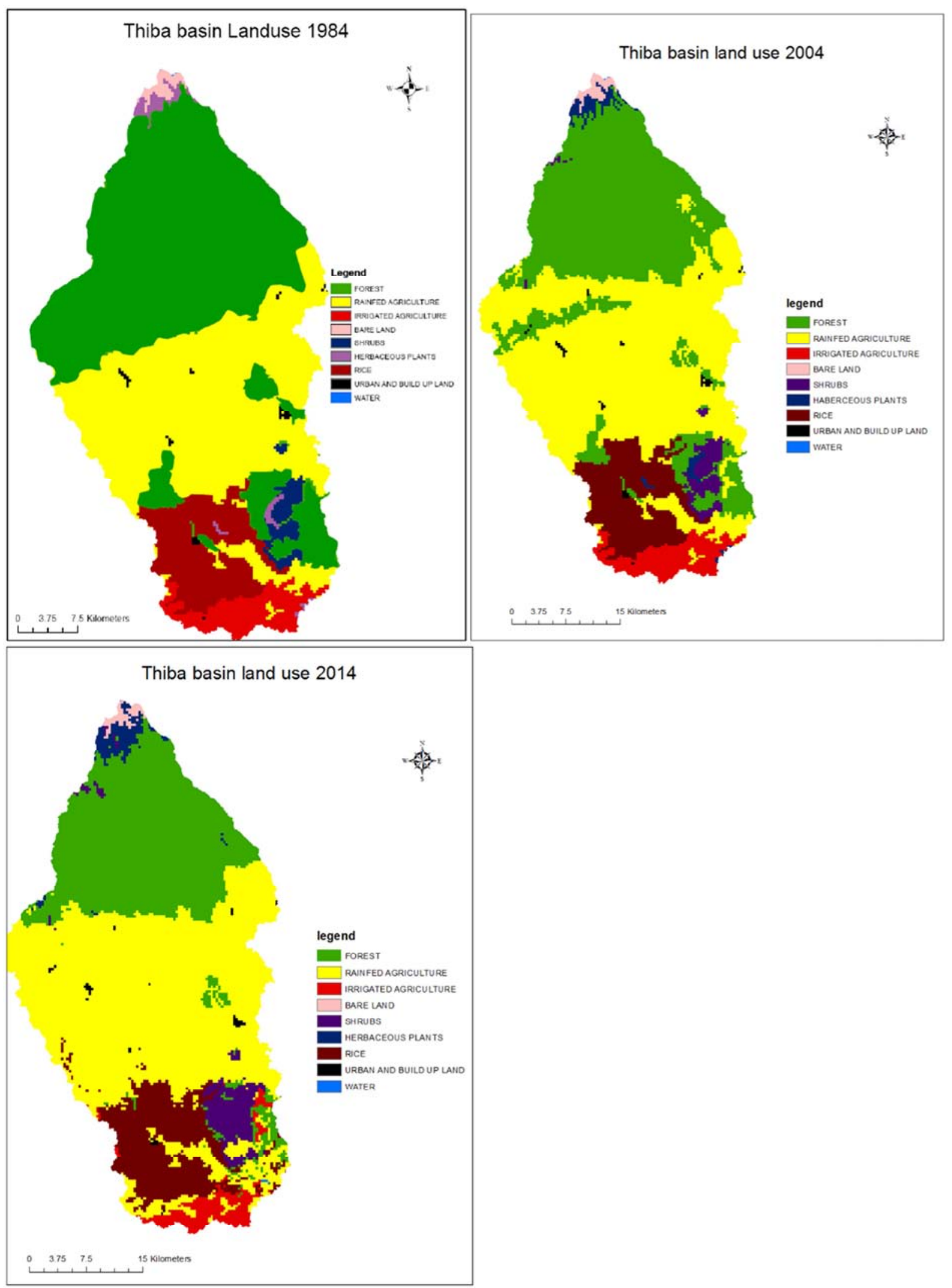

Figure 5. Land use/land cover changes in the Thiba River Basin in the period between 1984 and 2014. 
Table 2. Land use/land cover changes in the Thiba River Basin in the periods 1984-2004 and 2004-2014.

\begin{tabular}{lllllllll}
\hline Type of Land Use & Area $(\mathrm{Ha})$ & \% Area & Area $(\mathrm{Ha})$ & \% Area & Area (Ha) & \% Area & 1984-2004 \% Change & 2004-2014 \% Change \\
\hline & 1984 & & 2004 & & 2014 & & & \\
FOREST & 79430.5 & 48.2 & 59347.5 & 36.0 & 49137.0 & 29.8 & -12.2 & -6.2 \\
RAINFED AGRICULTURE & 60972.1 & 37.0 & 74977.7 & 45.5 & 83199.2 & 50.5 & 8.5 & 5.0 \\
IRRIGATED AGRICULTURE & 4132.2 & 2.5 & 6993.2 & 4.2 & 6120.0 & 3.7 & 1.7 & -0.5 \\
BARE LAND & 2933.0 & 1.8 & 1064.1 & 0.6 & 923.3 & 0.6 & -1.1 & -0.1 \\
SHRUBS & 6490.0 & 3.9 & 3534.6 & 2.1 & 3520.9 & 2.1 & -1.8 & 0.0 \\
HERBACEOUS PLANTS & 6946.5 & 4.2 & 2083.2 & 1.3 & 2376.7 & 1.4 & -3.0 & 0.2 \\
RICE & 3383.4 & 2.1 & 16224.5 & 9.8 & 18852.6 & 11.4 & 7.8 & 0.1 \\
URBAN AREA & 501.2 & 0.3 & 567.2 & 0.3 & 664.2 & 0.4 & 0.0 & 0.0 \\
WATER & 11.0 & 0.0 & 8.0 & 0.0 & 6.1 & 0.0 & 0.0 & \\
TOTAL & 164800.0 & & 164799.9 & & 164799.9 & & & \\
\hline
\end{tabular}

\subsection{Simulation Modeling with SWAT}

\subsubsection{Rainfall Data Validation}

Correlation analysis was carried out to determine the relationship between satellite obtained rainfall and observed rainfall data. The results (Fig. 6) showed a general agreement which is more prominent in months of low rainfall. However, in some months, there was over and under-estimation on rainfall and this was attributed to many reasons, among which could be: the recording errors by the river gauge readers, evaporation and wind influences. The high correlation coefficient $\mathrm{r}$ of 0.6 shows that satellite rainfall can be used for hydrological modeling with a good degree of confidence especially in areas with poor meteorological data.

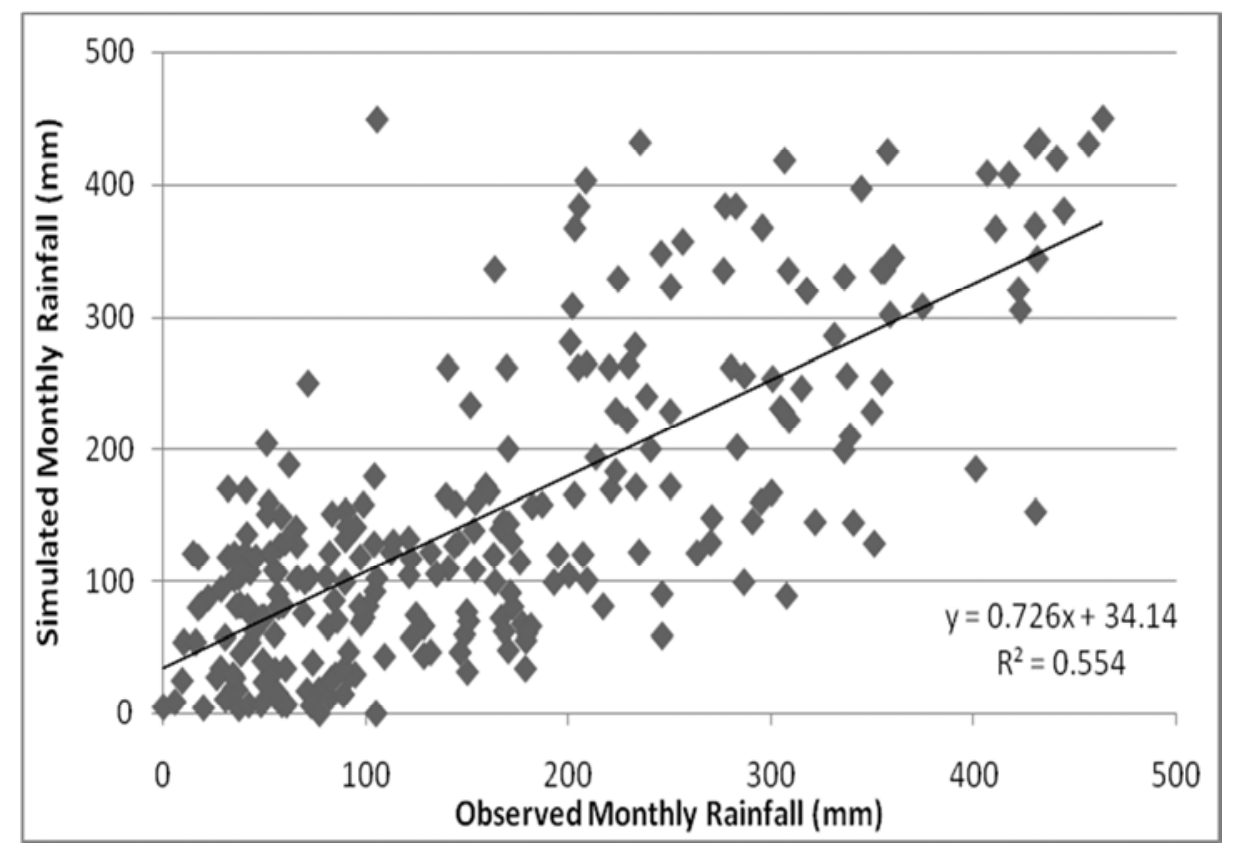

Figure 6. The relationship between simulated and observed monthly rainfall for Thiba river basin based on data collected at Newcastle forest station.

\subsubsection{Model Evaluation Results}

Nine parameters (Table 3) were found to be sensitive following sensitivity analysis thus considered for calibrating SWAT model.

Table 3. SWAT Model parameters and final fitted values used in the study.

\begin{tabular}{llllll}
\hline & Parameter & Lower bound & Upper bound & Final fitted value & Parameter \\
\hline 1. & SURLAG. Bsn & 0 & 24 & 5.3 & Surface runoff lag coefficient \\
2. & CN2. Mgt & 0.9 & 1 & 0.6 & Initial SCS CN II \\
3. & SOL_AWC. Sol & 0 & 1 & 0.8 & Available Water Capacity \\
4. & ESCO. Hru & 0.01 & 1 & 0.76 & Soil evaporation compensation factor \\
5. & GW_DELAY. Gw & 0 & 60 & 20.95 & Ground water delay \\
6. & GWQMN. Gw & 0 & 1000 & 2.54 & Threshold depth of water in the shallow \\
7. & REVAPMN. Gw & 0 & 1000 & 0.154 & aquifer required for return flow to occur (mm) \\
8. & GW_REVAP. Gw & 0.02 & 0.2 & 0.19 & Threshold depth of water in shallow aquifer for revaporization (mm) \\
9. & ALPHA_BF. Gw & 0 & 1 & 0.8 & Ground water revamp coefficient \\
\hline
\end{tabular}


The simulated daily flow matches the observed values for the calibration (1983-1988) and validation (1989-1993) periods with the coefficient of determination $\mathrm{R}^{2}=0.9,0.87$ and NSE $=0.82,0.79$, respectively. Values of $R^{2}>0.6$ and $N S>0.5$ for the calibration of the daily or monthly simulated stream flow are usually considered as adequate for an acceptable calibration [29]. The graphical presentation of results of the simulation during calibration period shown in Figures 6 and 7 shows good agreement between simulated and observed flows. Validation results are also illustrated by Figures 8 and 9. The results show that SWAT is able to simulate the hydrological characteristics of the Thiba River basin very well. Hence, the model was used to conduct hydrological response as result of land use change using the land use maps for the years 1984 and 2014 in the Thiba basin. Each of the two simulations used the same climate and soil data so that the effects of land cover change on hydrologic response were isolated.

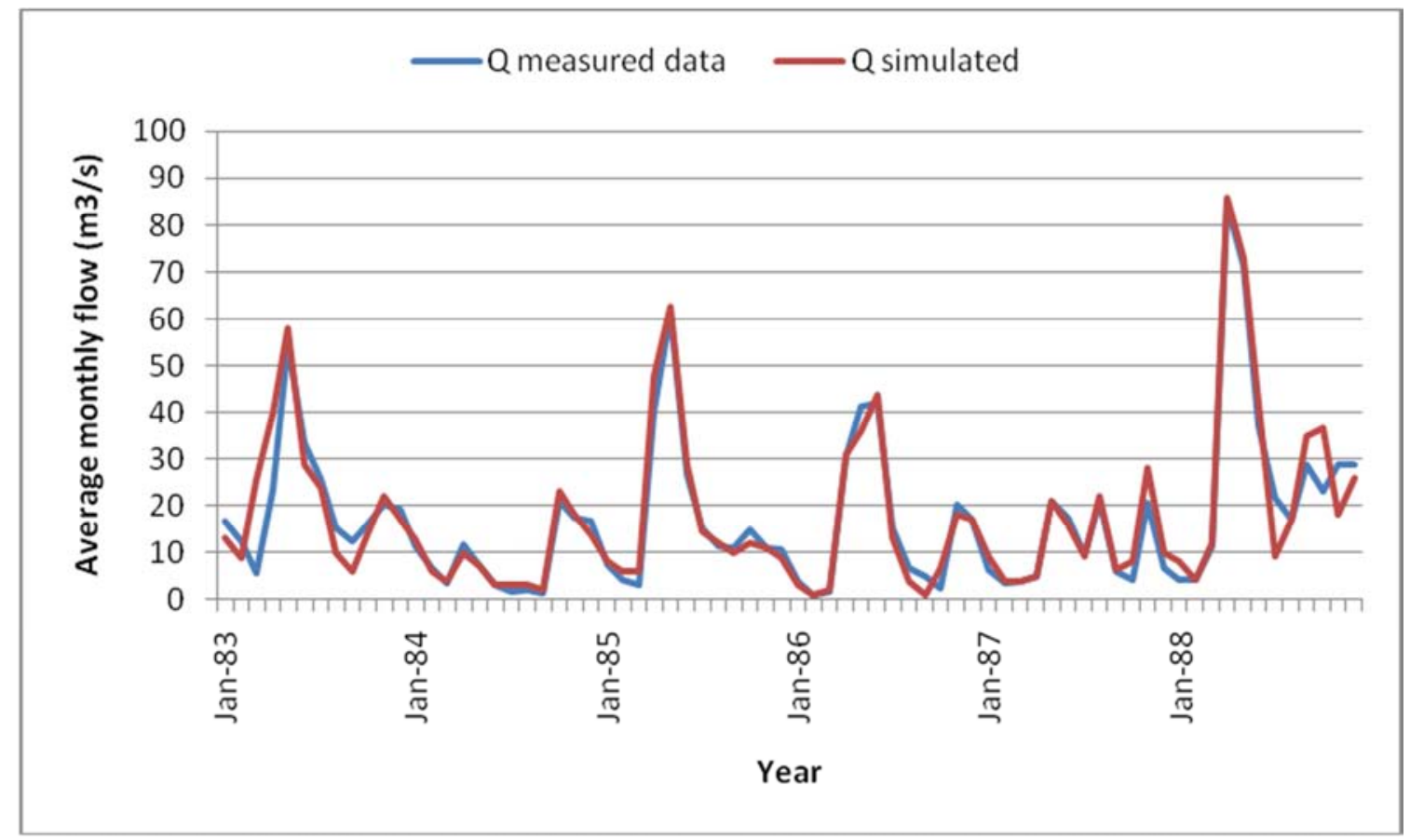

Figure 7. Observed and calibrated stream flow for Thiba River at catchment outlet 4DD02 between 1983 and 1988.

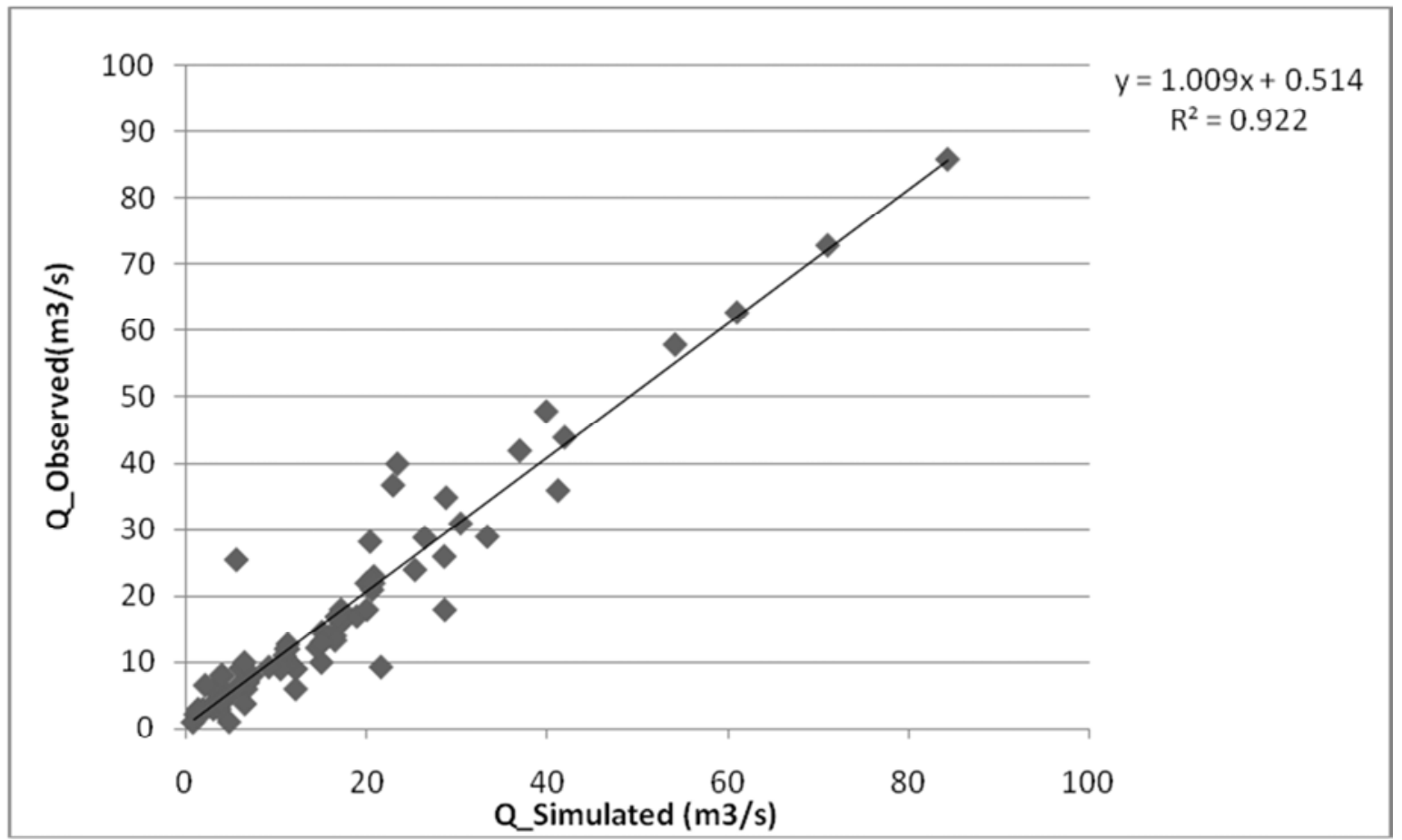

Figure 8. Comparison of observed and simulated stream flows of Thiba River Catchment outlet 4DD02 for calibration period between 1983 and 1988. 


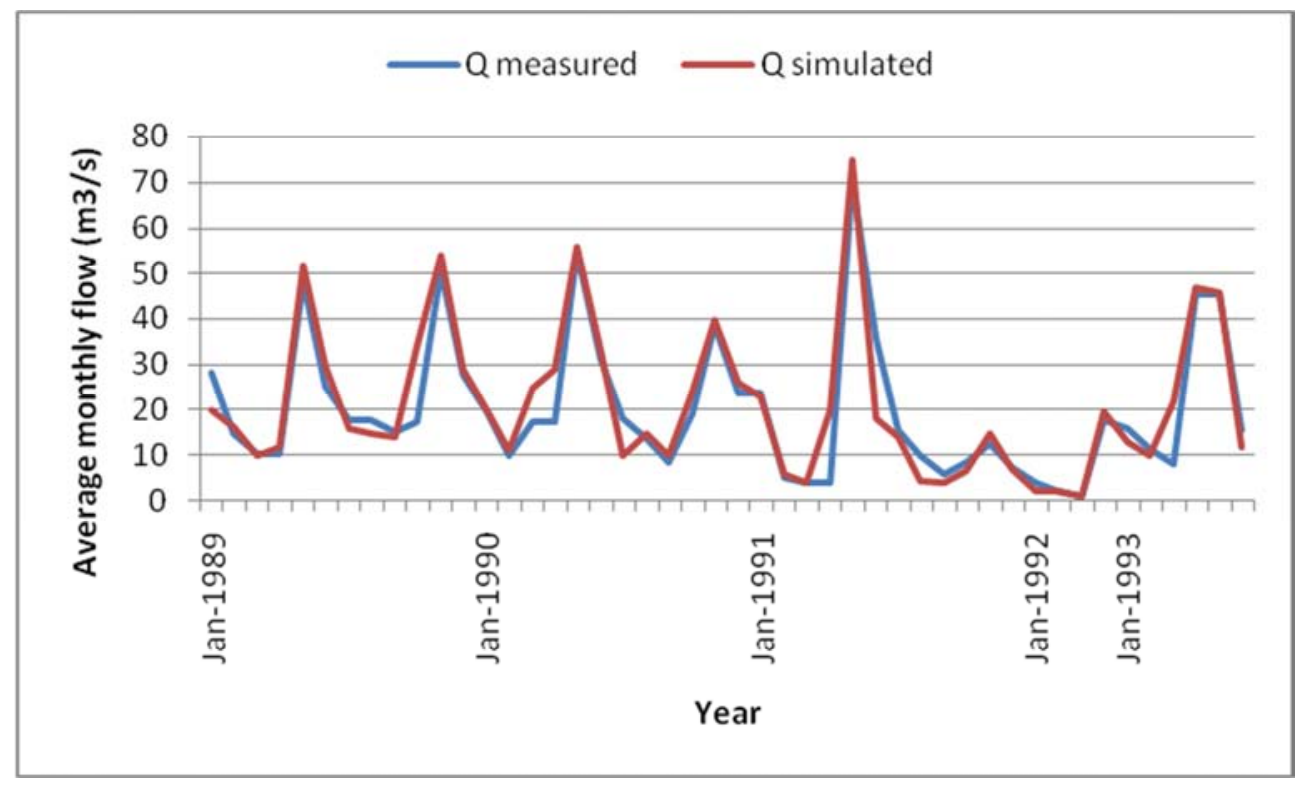

Figure 9. Observed and validated stream flow for Thiba River at catchment outlet 4DD02 between 1989 and 1993.

Table 4. Comparison of Measured and simulated monthly flow for calibration and validation simulations.

\begin{tabular}{lllll}
\hline \multirow{2}{*}{ Period } & \multicolumn{2}{c}{ Average monthly flow $\left(\mathbf{m}^{3} / \mathbf{s}\right)$} & \multirow{2}{*}{ ENS } & \multirow{2}{*}{$\mathbf{R}^{2}$} \\
\cline { 2 - 5 } & Measured & Simulated & 0.82 & 0.9 \\
\hline Calibration Period (1983-1988) & 17.22 & 17.89 & 0.79 & 0.87 \\
Validation Period (1989-1993) & 19.92 & 21.15 & & 0.92 \\
\hline
\end{tabular}

Table 4 indicates that the physical processes involved in the generation of stream flows in the watershed were adequately captured by the model. Hence, the model simulations can be used for various water resource management and development aspects.

\subsubsection{Impacts of Land Use Change on Stream Flow}

As indicated in the Table 5, the mean monthly stream flow for wet months had increased by $6.01 \mathrm{~m}^{3} / \mathrm{s}$ while the dry season decreased by $1.92 \mathrm{~m}^{3} / \mathrm{s}$ during the $1984-2014$ periods due to the land use and land cover change. When the simulated stream flow data for the wet months was subjected to students $t$ test, the observed value of $t(-3.81)$ came under rejection region (1.72) at 5\% significance level. We thus reject the null hypothesis and conclude that land use change has significant impact on stream flow during the wet season between the period of 1984 and 2014.

Table 5. Mean monthly wet and dry month's stream flow and their variability (1983-1993).

\begin{tabular}{llllll}
\hline Mean monthly flow $\mathbf{~}^{3} / \mathbf{s}$ & & & \multirow{2}{*}{ Mean monthly flow change } \\
\hline Land use/Land cover map 1984 & Land use/Land cover map 2014 & & Dry \\
\hline Wet months (April,Nov) & Dry months (Jan, Feb,Mar) & Wet months (April,Nov) & Dry months (Jan, Feb,Mar) & Wet & +6.01 \\
40.00 & 10.22 & 46.01 & 8.33 & -1.92 \\
\hline
\end{tabular}

Similarly, the simulated stream flows during the dry season were tested at $5 \%$ level of significance. The observed value of $\mathrm{t}$ (5.30) fell under the acceptance region (1.69). We thus accept the null hypothesis and conclude that Land use change between 1984 and 2014 has no significant impact on stream flow variability during the dry season.

The increase in stream flows can be attributed to the expansion of agricultural land over forest that results in the increase of surface runoff following rainfall events. We can explain this in terms of the crop soil moisture demands. Crops need less soil moisture than forests; therefore the rainfall satisfies the soil moisture deficit in agricultural lands more quickly than in forests there by generating more surface runoff where the area under agricultural land is extensive. And this causes variation in soil moisture and groundwater storage. This expansion also results in the reduction of water infiltrating in to the ground. Therefore, discharge during dry months (which mostly comes from base flow) decreases, whereas the discharge during the wet months increases. These results demonstrate that the land use and land cover change have a significant effects on infiltration rates, on the runoff production, and on the water retention capacity of the soil.

A similar study conducted in Hare River watershed, Southern Rift Valley Lakes Basin, Ethiopia by [30] showed a $12.5 \%$ increase in mean monthly discharge for wet months while in the dry season decreased by up to $30.5 \%$ during the 1992-2004 period due to the land use/cover change. [25] observed that higher runoff flows are expected in cropland than in forests due to the fact that rainfall satisfies the soil moisture deficit in agricultural land more quickly than in forests thereby generating more runoff in agricultural land. Lower infiltration rates are associated with agricultural land 
due to compaction and increase in soil bulk density. A similar study in Njoro catchment [28] found that forest conversion to agriculture led to a higher proportion of rainfall is being converted into surface runoff, rather than infiltrating into the soil and recharging the regional aquifer.

\section{Conclusion}

The study concluded that land use changes had taken place between 1984 and 2014 with major changes been decrease of forest cover $18.39 \%$ and increase in rainfed agriculture by $13.5 \%$. The SWAT model simulation results showed that the land use changes have significant impacts on stream flow modifications with wet season mean monthly flow increasing by $6.01 \%$ while dry season mean monthly flow decreasing by $1.92 \%$. Land use changes, especially upgrading of rain fed agriculture, are unavoidable due to increased food demand and declining agricultural productivity. Such changes are bound to have positive socio-economic impacts geared towards improving livelihoods, but could lead to negative impacts on the basin hydrology.

The process of domesticating SWAT model for given catchment basin has also been greatly facilitated by the development of Remote Sensing (RS) and Geographic information Systems (GIS) based interfaces which provides more straight forward means of translating digital land use, topographic, and soil data into model inputs. his has enabled better understanding of hydrologic response to catchment management decisions on hydrology of poorly gauged river basins

The uses of automatic calibration techniques were found to be convenient and highly efficient in model evaluation. The study recommends that the basin stakeholders should optimize utilization of abstracted water to avert future catastrophic stream flow fluctuations, possibly flooding during the wet season and low or dry riverbeds during the dry months. The high water demand in the dry months can be met by constructing water storage reservoirs to harvest the high runoff during the wet months Also, it's important that further research on impact of climate change be conducted to better understand the relationship between catchment hydrology and climate change.

\section{Acknowledgment}

I would in particular like to most sincerely thank Dr. Kitheka for the advice and interest in this study and for also for assisting me in successfully applying for the endowment fund from National Commission for Science Technology and Innovation (NACOSTI). I extend my sincere gratitude to NACOSTI for granting me research endowment fund which greatly assisted me in research related costs. I also wish to thank my family members especially my wife Mercy Samuel and Son Adrian Kasuni for enduring my parental absence during the course of my study. My friend and technical assistant in SWAT modeling, Jacob Mutua for tireless assistance during the course of study is much appreciated.
Lastly thank Kenyan government institutions which assisted me with data for this study namely Kenya Meteorological Department, Water Resources Management Authority and National Irrigation Board.

\section{References}

[1] A. Stipinovich, "Change in Land Cover and Water Abstraction: Modelling Runoff Effects in the Bot River Catchment," Department of Geography and Environmental Studies. University of Stellenbosch, Msc. Thesis, 2005.

[2] R. DeFries and K. N. Eshleman, "Land-use change and hydrologic processes: a major focus for the future," Hydrol. Process., vol. 18, pp. 2183-2186, 2004.

[3] K. Price, "Effects of watershed topography, soils, land use, and climate on baseflow hydrology in humid regions: A review," Prog. Phys. Geogr., vol. 35, no. 4, pp. 465-492, 2011.

[4] J. K. W. Ngaira, "Challenges of water resource management and food production in a changing climate in Kenya," $J$. Geogr. Reg. Plan., vol. 2, no. 4, pp. 97-103, 2009.

[5] V. U. Smakhtin, R. L. Shilpakar, and D. A. Hughes, "Hydrologybased assessment of environmental flows: an example from Nepal," Hydrol. Sci., vol. 51, no. 2, pp. 207-222, 2006.

[6] J. Gikonyo, "River water abstraction monitoring for the Upper Ewaso Ng'iro river basin, Kenya," in SPPE workshop madagascar, 1997, pp. 20-22.

[7] National Irrigation Board, "Special Assistance for For Project Formulation for Mwea Irrigation Development Project, Kenya," 2009.

[8] Muchiri M. L, "Climate change impacts on water use strategies in Mwea irrigation Scheme, Kirinyaga County, Kenya. Department of Environmental Education. Kenyatta University, Kenya.," 2013.

[9] Kirinyaga County, "Republic of Kenya Kirinyaga County First County Intergrated Report,” 2013.

[10] H.. Notter, B., MacMillan, L., Viviroli, D., Weingartner, R., Liniger, ". Impacts of environmental change on water resources in the Mt. Kenya region," hydrology, vol. 343, no. 12, p. 13, 2007.

[11] J. FAO, IIASA, ISRIC, ISSCAS, "Harmonized World Soil Database (version 1.2).," FAO, Rome, Italy IIASA, Laxenburg, Austria, 2012.

[12] J. H. Geertsma, R, Wilschut, L. I. Kauffman, "Review for the green water credits pilot operations in Kenya. Green Water Credits Report 8. ISRIC Report 2010/02. Wageningen, the Netherlands: ISRIC-World Soil Information.,” 2010.

[13] M. W. Ndegwa, "International Journal of Advances in Management and Economics An Assessment of the SocioEconomic Status of Rice Farmers in Mwea Irrigation Scheme.," Manag. J., vol. 3, no. 1, 2014.

[14] P. Maingi, J. Hutting, C. Njoronge, and K. Dijkshoorn, “Soil and terrain conditions for the Upper Tana River catchment, Kenya. Green Water Credits Report 11 / ISRIC Report 2010/09.," ISRIC - World Soil Information, Wageningen (47p. with data set), 2010. 
[15] A. Di Gregorio and J. Latham, "Africover Land Cover Classification and Mapping Project," L. Use, L. Cover Soil Sci., vol. I, 2000.

[16] Q. Liu, H. and Zhou, "Accuracy analysis of remote sensing change detection by rule based rationality evaluation with post-classification comparison," IInternational J. Remote Sens., vol. 25, no. 5, pp. 1037-1050, 2004.

[17] B. Vilaysane, K. Takara, P. Luo, and I. Akkharath, "Hydrological stream flow modelling for calibration and uncertainty analysis using SWAT model in the Xedone river basin, Lao PDR," Procedia Environ. Sci., vol. 28, pp. 380390, 2015.

[18] J. G. Arnold, D. N. Moriasi, P. W. Gassman, K. C. Abbaspour, M. J. White, R. Srinivasan, C. Santhi, R. D. Harmel, A. Van Griensven, M. W. VanLiew, N. Kannan, and M. K. Jha, "Swat: Model Use, Calibration, and Validation," Asabe, vol. 55, no. 4, pp. 1491-1508, 2012.

[19] L. R. Ahuja, M. J. Shaffer, J. D. Hanson, and K. W. Rojas, "Root Zone Water Quality Model Sensitivity Analysis using Monte Carlo Simulation," ASAE, vol. 43, no. 4, pp. 883-895, 2000.

[20] S. Sorooshian and V. K. Gupta, "Model calibration," in Computer Models of Watershed Hydrology, Water Resources Publications, Highlands Ranch, 1995, pp. 23-68.

[21] M. W. Van Liew, J. G. Arnold, and D. D. Bosch, "Problems and Potential of Auto-calibrating a Hydrologic Model," ASAE, vol. 48, no. 3, pp. 1025-1040, 2005.

[22] J. G. Arnold, D. N. Moriasi, P. W. Gassman, and M. J. White,
"SWAT : Model use, calibration, and validation,". Biol. Syst. Eng. Pap. Publ. Pap. 406., 2012.

[23] K. Abbaspour, "SWAT-Calibration and uncertainty programs (CUP)-User Manual," 2015.

[24] J. C. Refsgaard, "Parameterisation, calibration, And validation of distributed hydrological models," J. Hydrol., vol. 198, no. 1, pp. 69-97, 1997.

[25] F. Githui, W. Gitau, F. Mutua, and W. Bauwens, "Climate change impact on SWAT simulated streamflow in western Kenya.," Int. J. Clim., vol. 29, pp. 1823-1834, 2009.

[26] M. E. Coffey, S. R. Workman, J. L. Taraba, and A. W. Fogle, "Statistical procedures for evaluating daily and monthly hydrologic model predictions.," $A S A E$, vol. 47, no. 1, pp. 5968, 2004.

[27] P. Krause and D. P. Boyle, "Advances in Geosciences Comparison of different efficiency criteria for hydrological model assessment," Adv. Geosci., vol. 5, pp. 89-97, 2005.

[28] T. J. Baker and S. N. Miller, "Using the Soil and Water Assessment Tool ( SWAT ) to assess land use impact on water resources in an East African watershed," J. Hydrol., vol. 486, pp. 100-111, 2013.

[29] C. Santhi, J. G. Arnold, J. R. Williams, W. A. Dugas, R. Srinivasan, and L. M. Hauck, "Validation of the SWAT model on a large river basin with point and nonpoint sources," $\mathrm{J}$. Am. Water Resour. Assoc., vol. 37, no. 5, pp. 1169-1188, 2001.

[30] K. Tadele and G. Förch, "Impact of land use/cover change on streamflow: the case of Hare River Watershed, Ethiopia," Symp. (LARS), Arba Minch, Ethiop., pp. 80-85, 2007. 